\title{
Short-term survival of ammonites in New Jersey after the end-Cretaceous bolide impact
}

Neil H. Landman, Matthew P. Garb, Remy Rovelli, Denton S. Ebel, and Lucy E. Edwards

Acta Palaeontologica Polonica 57 (4), 2012: 703-715 doi: http://dx.doi.org/10.4202/app.2011.0068

A section containing the Cretaceous/Paleogene (= Cretaceous/Tertiary) boundary in Monmouth County, New Jersey, preserves a record of ammonites extending from the end of the Cretaceous into possibly the beginning of the Danian. The section includes the upper part of the Tinton Formation and lower part of the Hornerstown Formation. The top of the Tinton Formation is represented by a richly fossiliferous unit (the Pinna Layer) that contains many bivalves in life position as well as ammonite jaws preserved inside body chambers. Ammonites include Pachydiscus (Neodesmoceras) mokotibensis, Sphenodiscus lobatus, Eubaculites carinatus, E. latecarinatus, Discoscaphites iris, D. sphaeroidalis, D. minardi, and D. jerseyensis. The Pinna Layer probably represents a relatively short interval of time lasting tens to hundreds of years; it is conformably overlain by the Burrowed Unit, which contains a single fragment of Discoscaphites sp. and several fragments of E. latecarinatus , as well as several isolated specimens of ammonite jaws including two of Eubaculites. Examination of the mode of preservation of the ammonites and jaws suggests that they were fossilized during deposition of the Burrowed Unit and were not reworked from older deposits. Based on the ammonites and dinoflagellates in the Pinna Layer and the Burrowed Unit, these strata traditionally would be assigned to the uppermost Maastrichtian, corresponding to calcareous nannofossil Subzone CC26b. However, a weak iridium anomaly (500-600 pg/g) is present at the base of the Pinna Layer, which presumably represents the record of the bolide impact. Correlation with the iridium layer at the Global Stratotype Section and Point at El Kef, Tunisia, would, therefore, imply that these assemblages are actually Danian, provided that the iridium anomaly is in place and the ammonites and dinoflagellates are not reworked. If the iridium anomaly is in place, or even if it has migrated downward from the top of the Pinna Layer, the ammonites would have survived the impact at this site for a brief interval of time lasting from a few days to hundreds of years.

Key words: Ammonoidea, biostratigraphy, extinctions, iridium anomaly, Cretaceous/Paleogene boundary, New Jersey. 
Neil H. Landman [landman@amnh.org], Division of Paleontology

(Invertebrates), American Museum of Natural History, 79th Street and

Central Park West, New York, NY 10024, USA; Matthew P. Garb [mgarb@brooklyn.cuny.edu

], Department of Earth and Environmental Sciences, Brooklyn College and

Graduate School of the City University of New York, Brooklyn, NY 11210,

USA; Remy Rovelli [remyrovelli@gmail.com], Department of Earth and

Environmental Sciences, Brooklyn College, Brooklyn, NY 11210, USA; Denton S.

Ebel [debel@amnh.org], Division of Earth and Planetary Sciences, American

Museum of Natural History, 79th Street and Central Park West, New York, NY

10024, USA; Lucy E. Edwards [leedward@usgs.gov], United States Geological Survey, Mail Stop 926A, Reston, VA 20192, USA.

This is an open-access article distributed under the terms of the Creative Commons Attribution License (for details please see creativecommons.org), which permits unrestricted use, distribution, and reproduction in any medium, provided the original author and source are credited.

Foris Full text $(1,716.2 \mathrm{kB})$ 